\title{
Navigare necesse est
}

Keywords: derecho; legislación; jurisprudencia; animal

Autoridades académicas, representantes de la administración, compañeros, alumnos, señoras y señores

La frase 'navigare necesse est' (lo que importa es seguir navegando), se atribuye al general republicano Pompeyo, quien, según Plutarco, quiso de ese modo animar a su tripulación a seguir adelante en medio de una tormenta, sin pensar en los miedos, recelos o circunstancias adversas. Es una frase que se ha convertido en una enseña de energía, crecimiento y superación y, desde hace siglos, es muy popular. Fué el lema de la Liga Hanseática, y la han empleado, entre otros, Luis de Camoens, Petrarca y el poeta portugués Fernando Pessoa, a quien admiro profundamente, quien la usó en uno de sus poemas ("Navegare é preciso") parafraseando el final de la frase completa[1] : lo que importa es seguir navegando, vivir no lo es, para decir:

'vivir no es necesario, lo que es necesario es crear'[2].

Eso es lo que hoy quisiera transmitiros a todos los que habeis acudido a la clausura de la parte presencial de la $2^{\text {a }}$ edición del Master en Derecho Animal y Sociedad. Tanto a los Profesores, a los Alumnos, a todo el personal de la Universidad y de la Escuela de Postgrado, a las entidades colaboradoras, así como a los amigos y amigas que nos acompañan.

Cursar este master en este año 2013 es una decisión que os honra a los que os habeis embarcado en ella, pues, ante la dificultad de abrir paso a los Animales dentro del Derecho, habeis hecho una apuesta por una formación seria y profesional. Una decisión de navegar contra corriente. Gracias a todos los que haceis posible que un proyecto como éste, se vaya haciendo realidad, sin prisas pero sin pausas.

Lo que más me maravilla, en el día a día, cuando veo a los Alumnos en clase y a los Profesores que acuden a impartir sus conferencias, muchas veces con un gran esfuerzo personal, pues vienen de otros países y no se paran ni a hacer turismo, es la ilusión, el empeño y el interés. A algunos os he visto estudiar en la Biblioteca, preparar un trabajo, sugerir una mejora, llegar corriendo a clase dejando el despacho o la tarea cotidiana. A todos os he visto siempre animados y con ilusión.

Quiero estimularos a culminar con idéntica ilusión las tareas que os restan para obtener la titulación del Master: el Trabajo de Investigación y las Prácticas. Pero sobre todo, quiero animaros a dejar huella de vuestra formación allá donde esteis. Que se note que la mejora de la situación jurídica de los animales os importa. Que forma parte de vuestro "paisaje cotidiano" y que vais a poner lo mejor de vosotros mismos en que forme parte del "paisaje cotidiano" de muchos más. Se lo debemos.

Por cierto, hace poco ví un almohadón con una cruz en forma de aspa -casi como una bandera pirata-, que en una esquina llevaba escrito este dictum latino. Por descontado que no resistí la tentación, lo compré y hoy forma parte de mi 'paisaje cotidiano' más próximo. Lo miro y pienso: claro que sí, adelante!: navigare necesse est!. 
[1] Navigare necesse est, vivere non necesse

[2] PESSOA, F., Navegare é preciso: Quero para mim o espírito desta frase,/transformada a forma para a casar como eu sou: / Viver não é necessário;/o que é necessário é criar.' 